\title{
Financing Development Stage Biotechnology Companies: Reverse Mergers vs. IPOs
}

\author{
Mark J. Ahn, Robert B. Couch, and Wei Wu ${ }^{1}$
}

${ }^{1}$ Mark J. Ahn, PhD, Associate Professor of Global Management at Atkinson Graduate School of Management, Willamette University. He can be reached at mark@pukanapartners.com.

Robert B. Couch, PhD, Assistant Professor of Finance Atkinson Graduate School of Management, Willamette University. He can be reached at rcouch@willamette.edu.

Wei Wu, PhD, Assistant Professor of Finance Atkinson Graduate School of Management, Willamette University. He can be reached at wwu@willamette.edu. Tel: 503-370-6227. Fax: 503-370-3011. 


\begin{abstract}
We examine reverse mergers (RMs) in the biotechnology industry and find that, when compared to initial public offerings (IPOs), RMs are smaller, have significantly lower market valuations relative to size, and generally invest less. We also find that RMs exhibit positive abnormal returns on the announcement date and throughout the first year after the RM event. In looking at liquidity measures, we find that RMs tend to be less liquid than IPOs and that illiquidity is greater during the six-month lock-up period following the $\mathrm{RM}$ event. Thus, RMs may be an appropriate alternative financing vehicle in capital intensive, high-risk biotechnology companies which require accessing deeper and larger pools of investors in public capital markets across multiple milestone periods in a "pay for progress" environment.
\end{abstract}

Key words: biotechnology, reverse merger (RM), initial public offering (IPO). 


\section{Introduction}

Understanding the process by which disruptive technology platforms access capital and achieve increasing returns to scale is critical in high technology industries generally ${ }^{1}$ and in biotechnology specifically $^{2}$ due to the degree valuation relies on intangible assets and human capital. Disruptive technologies from emerging companies hold great promise to exploit innovation, accelerate growth, and create value. ${ }^{3}$ However, disruptive technology platforms often face significant legitimacy hurdles due to their small size and liability of newness, as well as their relative lack of power when it comes to multiple stakeholder claims, control over resource flows, and business partner relationships. ${ }^{4}$

While the liability of newness is a factor for all new ventures, it is exacerbated for firms in emerging industries created around new technologies. ${ }^{5}$ As such, organizations in emerging industries at the frontiers of biotechnology development have to learn new roles with limited precedent for their actions, and they must educate the broader community to establish ties in an environment that may not fully understand or value their existence while simultaneously accessing financing. Moreover, the type of financing approaches chosen by biotechnology firms was found to impact survival rates ${ }^{6}$ and have a "differential impact on speed to market, control of direction, degree of technological risk, and capability development."7 This study explores two alternative public financing approaches, RMs (reverse mergers) versus IPOs (initial public offerings), for development stage biotechnology companies which require access to successively larger and deeper pools of capital to conduct advanced clinical development and establish commercialization capabilities.

The rest of this article is organized as follows. First, we offer a more detailed discussion of the biotechnology sector, focusing specifically on the current financial landscape. Next, we characterize our data sample and sources. Then we analyze the financial characteristics of biotech RMs relative to biotech IPOs and analyze the abnormal return characteristics of biotech RMs, again comparing them to biotech IPOs. Finally, we consider liquidity measures of biotech RMs around the announcement date and the RM event date, and around the IPO issue date. 


\section{Financial Challenges in Biotechnology}

Biotechnology can be defined as "the use of cellular and biomolecular processes to solve problems or make useful products.” ${ }^{8}$ Human therapeutics has been the largest segment of the biotech industry. The US Food and Drug Administration (FDA) approved the first biotechnology drug in 1982. Since then, the biopharmaceutical industry has had 254 drugs approved for 385 indications, with over $\$ 70$ billion in sales in 2007. Further, another 400 drugs targeting over 200 diseases, including various cancers, heart disease, AIDS, and arthritis, are in clinical development, attracting over \$24.8 billion in financing. As fully integrated biotechnology giants such as Genentech, Amgen, and Biogen-Idec have emerged, the market valuation of the biotechnology industry has recently surpassed pharmaceutical firms.

In 2009, the net income of publicly traded biotechnology companies in the United States reached an unprecedented $\$ 3.7$ billion, a dramatic increase from $\$ 400$ million in $2008 .{ }^{9}$ In addition, the biotechnology industry is an important source of new venture creation with 692 publicly listed firms in North America, Europe, and Asia-Pacific. ${ }^{10}$ In 2008, bioscience research and development (R\&D) totaled nearly \$32 billion, which accounted for more than 60 percent of all US academic R\&D expenditures. Additionally, while the private sector experienced a 3.5 percent increase in employment from 2001 to 2008, employment in the bioscience sector increased 15.8 percent.

Despite this tremendous investment, productivity over the years has been decreasing, with higher costs of drug research and longer clinical development timelines. The average drug takes over $\$ 1.0$ billion and 12 years to go from laboratory to approval. Part of the reason for rising development costs is the high failure rate of product candidates in clinical trials due to increasingly specific molecular targets for unmet diseases - which necessarily increases development risk, complexity of biologic systems with compensating mechanisms, overlapping intellectual property claims, and shifting regulatory requirements. For the drug candidates that progress from animal testing into human clinical trials, the overall success rate is 11 percent. In other words, nearly nine out of every ten products entering clinical trials will fail, and some disease areas are proving to be even more challenging, for instance, oncology success rates are 
approximately 5 percent. Furthermore, getting approval is no guarantee of commercial success. To date, only four of ten products that reach the market achieve profitability. This lack of development productivity (either increasing the value created or decreasing the time required to create value) has taken its toll on industry financial performance. Out of the nearly 350 publicly traded biopharmaceutical companies, only a small minority have reached sustainable profitability. The heavily regulated, high complexity biopharmaceutical environment characterized by binary risk, disproportionately impacts the sustainability of start-ups. ${ }^{11}$

Notwithstanding, a critical and somewhat unique feature of the biotech industry is the significant amount of value that can be generated during various phases of product development that is reflected in the ability of start-up companies to raise successive rounds of private and public capital prior to achieving sales or net income. Significant value can be created in terms of successive private rounds of financing at increasing enterprise valuations, obtaining liquidity by accessing public capital markets (e.g., IPOs, $\mathrm{RMs}$ ), as well as by executing trade sales and alliances with larger biopharmaceutical companies years before realizing sales and profitability. In this context, development stage biotech firms represent real options-defined as the right but not the obligation to make a series of business decisions (e.g., incrementally invest to advance a drug candidate from Phase II to Phase III clinical trials) by investors and/or strategic alliance partners. ${ }^{12}$

The irregular nature of biotechnology financial markets, often characterized as "financing windows," increases operating risk and uncertainty (e.g., IPOs not being effective during a general market downturn). ${ }^{13}$ As a result of large capital requirements, long lead times, and episodic successes and failures, biotech financing cycles have been characterized by periods of high euphoria, only to be followed by deep disillusionment after a cluster of high-profile product failures occur. This subjects early stage companies to high degrees of financing risks, regardless of their operational progress. While the industry has matured, the predominant venture capital financing model—one product platform or one product, a few investors who provide seed capital, and a long incubation period leading to sale or an 
IPO—has not markedly changed, despite reduced numbers of exits and modest overall risk-adjusted rates of return. ${ }^{14}$

Financing approaches to biotechnology financing can be broadly categorized into private and public financing (see Figure 1). In biotechnology, private financing sources are typically derived from academia (e.g., majority of initial new drug (IND) applications to the FDA are from universities and research institutes), angel investors (e.g., wealthy individuals and groups), and venture capital (e.g., pools of private equity funds that establish limited partnerships to invest in early stage, high technology companies). Private equity is typically seen as required in early stages of company development due to information asymmetry between management and shareholders, such that more active governance (e.g., venture capital acquires board of director seats and places restrictions on capital deployment) is required.

Figure 1 about here

Public financing, on the other hand, is achieved by selling newly issued shares in a publicly traded company to individual and institutional investors (e.g., mutual funds, hedge funds). There are two pathways for private biotechnology companies to obtain a public share listing to enable trading liquidity, and access to larger and deeper pools of financing: IPOs and RMs . IPOs are the initial sale of stock that transforms a private company into a public company with financial disclosures and filings as required by the US Securities Exchange Act of 1934.

While biotech IPOs are open to a small number of firms that can achieve successive rounds of venture capital and justify the large underwriting costs of investment banks, development stage R\&D firms have also proven to be difficult to price and volatile ${ }^{15}$ despite investment syndicates, strategic alliances, or other signaling mechanisms. ${ }^{16}$ From 2006 through 2010, for example, there were 58 biotechnology IPOs with an average pre-money valuation of \$269.0 MM, an average financing of \$102.1 MM, and returned 24 percent. ${ }^{17}$ As a result, the number of IPOs has been on a steady downward trend (see Figure 2). As an 
example of the "financing window" effect, consider Boston-based BG Medicine, a developer of molecular diagnostics based on biomarkers, with a focus on cardiovascular, central nervous system, and autoimmune indications, which filed for an IPO in August 2007 to raise $\$ 80$ million at $\$ 13$ to $\$ 15$ per share, but withdrew the proposal in January 2008 citing market conditions. The company subsequently amended its IPO in January 2011 to raise \$33.3 million shares at \$7 per share.

\section{Figure 2 about here}

A Reverse Merger (RM) occurs when a public company purchases a private company but the private company becomes the controlling entity after the transaction. RMs are another way a private company may achieve a public listing and have increased popularity (see Figure 3). The publicly traded company is called a "shell" since it has little or no business operations and derives its value with its organizational structure. RMs are often completed at far lower valuations compared to IPOs and may be seen as alternatives to being "priced out” by investment bank underwriters who require larger transaction sizes to justify their efforts. RMs are also often cited as a means to avoid the costly and lengthy process of an IPO, which includes stringent requirements imposed by the Sarbanes-Oxley Act of 2002, with studies finding RMs costing $\$ 200,000$ to $\$ 300,000$ and two to 12 months less than an IPO. ${ }^{18}$ Once public, companies can subsequently access wider and deeper pools of investors such as individuals, hedge funds, and mutual funds.

\section{Figure 2 about here}

An example of a firm using an RM to gain access to liquidity early in its research and development life cycle was Cougar Biotechnology (CB). In 2003, CB was formed to license early stage technologies from Biotechnology General (BTG) and Emory University. In 2005, the private company simultaneously obtained a convertible bridge financing of $\$ 6.1$ million, which was converted into common stock after completing an RM to obtain an over-the-counter (OTC) exchange listing. In 2005, CB used the proceeds 
to conduct $\mathrm{Ph} \mathrm{I/II} \mathrm{human} \mathrm{clinical} \mathrm{trials} \mathrm{of} \mathrm{abiraterone} \mathrm{acetate.} \mathrm{Based} \mathrm{on} \mathrm{successful} \mathrm{clinical} \mathrm{results,} \mathrm{the}$ company completed a \$50 million financing via a private placement or PIPE (private investment in public equity). In June 2007, CB reported promising interim Ph II clinical data. In December 2007, the company raised an additional \$87 million through another PIPE financing. In April 2008, CB commenced its registration-seeking Ph III clinical trials in metastatic, castration resistant prostate cancer in patients who progressed after docetaxel-based chemotherapy failed, under an SPA (special protocol assessment) approved by the US FDA. During the Phase III clinical trial, Johnson \& Johnson acquired CB for \$1.0 billion in a cash tender offer in May 2009.

Notwithstanding the above successful example of $\mathrm{CB}$, however, studies have found mixed overall performance results when comparing RMs to IPOs-with some showing higher, ${ }^{19}$ some neutral, ${ }^{20}$ and some lower abnormal returns. ${ }^{21}$ As such, our research seeks to explore the role of RMs versus IPOs in the context of the high risk, development stage, biotechnology industry sector. While RMs seem to be increasing in popularity in the biotech sector, existing research has not examined the utility and performance of biotech RMs as a means for expanding industry growth opportunities for early stage companies who access successive rounds of capital in a "pay for progress" environment. ${ }^{22}$ Further, besides shedding light on how RMs play a role in the biotech industry, our aim is to learn from the biotech industry about the processes and challenges of raising capital to finance innovative research in a context that entails significant long-term risks, which are difficult to monitor.

\section{Data}

Our sample of biotech RMs is drawn from two sources, the Securities Data Corporation's (SDC’s) International Mergers and Acquisition database and Windhover's strategic transaction database. The comprehensive data offered by SDC cover mergers and acquisitions (M\&As) while the Windhover data are specialized in alliances, financings, and M\&As across biopharmaceuticals, devices, diagnostics, and tech transfers. The SDC database incorrectly categorizes "rollups" and other forms of industry consolidation as RMs, and improperly categorizes many ordinary IPOs and M\&As between public 
companies as RMs. Windhover, on the other hand, does not remove the deals that have withdrawn after the initial announcement. As a result, we cross validate our sample selection using both databases.

Our final sample of biotech RMs is filtered based on the following criteria: (1) firms have Standard Industrial Classification (SIC) codes of 2833-2836 and 8731-8733; (2) the deal synopsis in SDC or the deal headline in Windhover clearly indentifies the deal as a RM; (3) the deal is between a private company based in the US and a public firm listed on a U.S. stock exchange; (4) the deal has both an announcement date and an RM even date, and it must be completed between 1/1/2000 and 12/31/2009; (5) firm-specific financial information is available from Compustat; (6) stock-related information is available from Center for Research in Security Prices (CRSP). The imposition of these criteria leaves us with a total of 29 RMs from 2000 to 2009.

We compare biotech RMs with biotech IPOs. Biotech IPO data are taken from SDC’s Global New Issues database. This sample is filtered based on the following criteria: (1) the offering companies must have SIC codes of 2833-2836 and 8731-8733; (2) the offering is by a U.S.-based private company on a US-based exchange; (3) the offering is not a roll-up IPO; (4) financial information is available from Compustat; (5) stock-related information is available from CRSP. The imposition of these criteria leaves us with a total of 137 biotech IPOs form 2000 to 2009.

We do not include financial data on private companies prior to the time that they go public via RMs as the data are not reliable and very sparse in the databases. Instead, we collect the financials and conduct market value calculations based on the most adjacent annual report day following the RM event date and the issue date for IPOs.

\section{Financial Characteristics of Biotech RMs}

In Table 1 we compare biotech RMs with biotech IPOs. Because of the skewed nature of many of the non-return variables, we do an analysis of medians rather than focusing on means, as is common in IPO studies. To test for statistical significance regarding the difference between RM and IPO medians, we use the Wilcoxon two-sample median z-test. 
In Panel A, we look at various measures of size. The first two that we look at are total assets (TA) and sales, since these are the two most common measures of size in financial studies. Since young biotech firms seldom have significant sales revenue, and since the amount of measurable real assets is typically quite small and non-representative of the real value of the firm, these measures are very noisy measures of size. Because of this, we look at two other size measures: number of employees and market capitalization (Mkt Cap). Number of employees is a measure that captures the current size of the firm whereas Mkt Cap is a measure of the market's expectations related to the expected future potential of the size and value of the firm. In the remaining panels of Table 1, we use these four measures of size as scaling variables for alternative firm measures aimed at capturing the financial health, investment, and growth aspects of our sample of firms.

\section{A. Size and Productivity}

As measured by TA, employees and Mkt Cap, RMs are significantly smaller than IPOs (see Table 1, Panel A). As measured by sales, the difference is not statistically significant. These results are consistent with our expectations since the relative cost of going through the IPO process is larger for smaller firms than larger firms.

The difference in size is most pronounced when measured by Mkt Cap, where IPOs are nearly 20 times as large as RMs. In contrast, the number of employees in IPO firms is only about 30 percent larger than RM firms; sales are 46 percent larger and TA are 68 percent larger for IPO firms than RM firms. This highlights the degree to which tangible measures of size (TA, sales, and employees) are measuring only the tip of the iceberg with respect to actual, market value. The most obvious difference between RMs and IPOs is the difference in the way the market values them. This point will be explored in more depth below.

Looking at sales divided by TA, we find that more sales are generated for RMs than IPOs, but the difference is not significant. Moreover, both sales and TA are likely very noisy measures of biotech firm 
value, health, and potential, so it would be hard to draw strong inferences from this ratio anyway.

Looking at book equity divided by Mkt Cap, we find that RMs have a higher ratio than IPOs. This corroborates our interpretation above that RMs generally receive lower valuations by the market than IPOs, when scaled by accounting measures of firm size. Looking at sales as a percentage of Mkt Cap, we find a similar result, presumably for similar reasons: RMs either have less access to growth financing, or less strategic reason to grow as fast as IPOs. When we look at capital expenditures (CAPX) scaled by Mkt Cap, we find the opposite result, that RMs have more relative CAPX than IPOs. This result is probably best interpreted in terms of the valuation effect discussed previously: market valuations per dollar invested are lower for RMs than for IPOs since RMs have not gone through the same vetting process of IPO book-building and hence entail more operational and liquidity risk.

Looking at Mkt Cap scaled by the number of employees, we find that RMs have lower valuations per employee. This suggests, again, that IPO firms have greater value and growth potential than RM firms, as reflected in investor confidence and interest.

Looking at TA divided by number of employees, we find that RMs have fewer assets per employee. This suggests that RM employees have less access to capital, and perhaps technology, than IPO employees. Interestingly, this raises a question regarding the chicken or the egg: does higher valuation, and higher expected valuations, lead firms to accumulate more assets per employee; or, does greater assets per employee lead to higher valuations? Unfortunately, our data are not able to speak to this question, though our hunch is that although both effects feed off each other, greater asset investment per employee is probably a result of more promising technological development and potential.

\section{B. Financial Health}

Looking at current liabilities, we find that RM firms have significantly more current liabilities than IPO firms when scaled by TA, employees, and Mkt Cap, as shown in Panel B of Table 1. The difference is not statistically significant when current liabilities are scaled by sales. This suggests RMs are more 
credit-constrained than IPOs.

Looking at long-term debt, we find that, relative to IPOs, RMs hold less debt relative to TA, sales, and employees, although the difference is not statistically significant. When scaled by Mkt Cap, however, RMs are actually shown to have more debt than IPOs, though this difference is only marginally significant $(\mathrm{p}$-value $=0.105)$. We interpret this result as an indication that IPOs have greater debt capacity, but this greater debt capacity is strongly correlated with the same factors driving the high relative valuations of IPOs.

Looking at free cash flow, we find that RMs tend to have greater relative free cash flows than IPOs when using non-market scaling variables. This is consistent with the manner in which young biotech firms are primarily in the game of investing in research and development of products that have only future value rather than an ability to generate current cash flow. Thus, it seems that IPOs have a greater capacity to incur negative free cash flows than RMs. This is likely an indication of strategic investment rather than an indication of a deeper problem, as negative free cash flow is frequently indicative of larger, mature firms, or firms in other industries.

\section{C. Investment}

Looking at research and development $(\mathrm{R} \& \mathrm{D})$ expenses, we find that when $\mathrm{R} \& \mathrm{D}$ is scaled by sales, the ratio is smaller for RMs than for IPOs, as shown in Panel C of Table 1. However, when scaled by Mkt Cap, RMs are found to invest more in R\&D than IPOs. These results suggest that the market valuation multiplier that IPOs experience relative to RMs is not driven solely by R\&D expenses. In other words, since R\&D measures tend to be higher for IPOs than RMs when non-market scaling variables are used, IPOs invest relatively more in $R \& D$ than $R M s$; however, since the ratio of $R \& D$ to $M k t$ Cap is significantly lower for IPOs than for RMs, market valuations must be driven by more than just the differential in R\&D.

Looking at CAPX, we find results that are similar to R\&D: RMs are found to invest less than IPOs 
when scaled my non-market variables, and more when scaled by Mkt Cap, and these differences are all statistically significant at the one percent level. This result is consistent with the idea that markets are more optimistic about IPO growth and value prospects, though the value effect is stronger than a pure investment-growth effect.

\section{Abnormal Returns}

In Table 2, we show cumulative abnormal returns (CARs), net the CRSP value-weighted index, for biotech RMs and biotech IPOs. For biotech RMs, we consider returns around the both the RM announcement date (Panel A) and event date (Panel B), which is the effective date that the RM occurs. IPOs are considered in Panel C. Figure 4 shows how CARs behave on a daily basis around the RM announcement and event dates, and after the going-public issue date for IPOs.

\section{Figure 4 about here}

\section{A. RM Announcement Date}

Prior to the announcement date, we do not find significant CARs, as shown in Panel A of Table 2. On the announcement date, we find a statistically significant mean CAR of 23 percent. During the first month, or 21 trading days, after the announcement, we find mean CARs of 33 percent, which represents an additional CAR of 10 percent after the first day announcement day return. Over the first six months after the announcement day, or 126 trading days, mean CARs increase slightly to 39 percent. Over the first 12 months, or 252 trading days, mean CARs increase an additional 20 percent to 59 percent. All of these means for CARs are statistically significant, although the first day and first month returns are significant at the one percent level whereas the other returns are only significant at the 5 percent level.

\section{B. RM Event Date}

In Panel B of Table 2, we show CARS based on the RM event date. During the month prior to the RM event date, from 21- through 2-days prior, we find mean CARs of 7 percent, which is not statistically 
significant. On the day prior to the event date, we find mean CARs of 11 percent, which is statistically significant at the one percent level. Since the RM event date should already be public information on the day before the event date, this abnormal return could reflect a positive news event regarding resolved uncertainty as to the possibility that the RM might not actually take place. Alternatively, this abnormal return could reflect hype surrounding the transaction, or other behavioral transactions or trading behavior associated with the RM event.

On the event date, we find mean CARs of -0.40 percent, which is not statistically significant. During the month after the event date, we find mean CARs of -12 percent, which is statistically significant at the one percent level. This negative CAR could be a reversal of the run-up on the day prior to the event.

During the six-month (126 trading days) lock-up period after the RM event date, we find mean CARs of -2 percent, which is not statistically significant. During the six months after the lock-up period, from six months to one year after the event date, we find mean CARs of 15 percent, which is not statistically significant.

\section{C. IPO Date}

Since stock prices prior to the issue date for IPOs are not publicly available, the first CAR event window we look at for IPOs is the IPO issue date. For biotech IPOs, we find mean abnormal returns on the first trading date of 4 percent, which is statistically significant at the one percent level. During the first month, or 21 trading days, and during the first six months, or 126 trading days, we find that mean CARs decreases to one percent, which is not statistically significant. However, after the typical six-month lockup period, we find that CARs are 5 percent, which is statistically significant at the 10 percent level.

\section{D. Multivariate Regressions}

Table 3 reports multivariate regression coefficients using as the dependent variable CARs by RM announcement date. On the day of announcement, $R \& D$ has a positive and significant coefficient when scaled by TA and by Mkt Cap. This suggests that the market in fact anticipates that higher R\&D-intensive 
RMs should be priced higher than RMs with less R\&D investment. This R\&D effect remains significant in several of the post-announcement event windows. In post-announcement event windows, current liabilities scaled by Mkt Cap also exhibit a positive and significant effect on CARs, whereas long-term debt scaled by Mkt Cap exhibits a negative and significant effect on one-year post-announcement CARs. These results may reflect credit constraints with shorter-term liabilities being incurred because of lack of good long-term financing offers, resulting in lower initial market valuations and higher subsequent returns.

Table 4 reports multivariate regression coefficients using as the dependent variable CARs by the RM event date. On the day prior to the RM event, both long-term debt and current liabilities have positive and significant coefficients when scaled by Mkt Cap. This is likely due to the fact that firms with higher liabilities effectively have a more leveraged bet on the success of the RM process being successfully consummated, which is something that investors become significantly more confident about on the day prior to a realized RM event. During post-event windows, current liabilities scaled by Mkt Cap continue to have a positive and significant sign, whereas the coefficient on long-term debt scaled by Mkt Cap becomes negative. This is the same result as was found in Figure 7 for the announcement date. Regarding investment variables, CAPX exhibit a positive and significant effect on post-event CARs when scaled by TA or Mkt Cap. This is similar to the result found for R\&D investment in Figure 7 for the RM announcement date, but it is curious that R\&D was found to be significant in that case but CAPX was not, and now, when looking around the RM event date, the opposite is true. The one other variable that is statistically significant in the post-event period for RMs is free cash flow scaled by Mkt Cap. The positive sign on this variable may be the result of a relatively short horizon in which some RM firms are scrutinized after the RM event by investors according to their ability to generate cash flows. As will be discussed below, this is in contrast to IPO firms.

Table 5 reports multivariate regression coefficients using as the dependent variable CARs for IPO firms by the IPO issue date. As with RMs, we find positive and significant coefficients for current 
liabilities and R\&D, both scaled by TA, in the post-event window. Like with RMs, the sign on free cash flow scaled by Mkt Cap is statistically significant; however, in this case, the sign is negative. This could be indicative of a longer-investment horizon associated with larger IPO firms having gone through a more rigorously scrutinizing process of going public than RM firms. The one other statistically significant (at the 0.05 level or higher) variable is the log of Mkt Cap which has a positive sign. This is somewhat surprising, as size has not been found to predict abnormal returns in other IPO studies. On our interpretation, this finding corroborates our belief regarding the relative financial advantages that large IPO firms enjoy, and are able to exploit, in the biotech industry.

\section{Liquidity}

Although there are many potential sources for the relatively low valuations and subsequent high abnormal returns documented in the previous section for biotech RMs, we focus here on the issue of liquidity. First, we motivate and define four measures of liquidity, then we move on to statistical analysis of these measures in our sample.

\section{A. Measuring Liquidity}

Based on a prior survey of empirical and theoretical liquidity asset pricing results, we use four measures of liquidity. ${ }^{24}$ First, we construct a share turnover ratio, Turnover, by dividing the total number of shares traded by the number of shares outstanding for a trading day and then average the daily ratios over a sample period to have the mean share turnover ratio:

$$
\text { Turnover }=\frac{1}{T} \sum_{t=0}^{T} \frac{\text { number of shares traded on day } t}{\text { number of shares outstanding on day } t}
$$

Next, we define Volatility as the standard deviation of daily returns, annualized by multiplying by the square root of the number of trading days in a year. That is, if $r_{t}$ is the return on day $t$, and there are $T$ periods in the relevant subsample, and $\bar{r}$ is the average return of the relevant subsample, then 


$$
\text { Volatility }=\sqrt{\frac{252}{T-1} \sum_{t=0}^{T}(r-\bar{r})^{2}}
$$

Besides these two relatively simple measures, we consider two more sophisticated measures that have been shown to be good measures of liquidity, both empirically and theoretically. Lesmond, Ogden, and Trzcinka $^{25}$ consider the proportion of days with zero returns as a proxy for liquidity. There are two key arguments that support this measure. First, stocks with lower liquidity are more likely to have days with little to no trading activity, and thus zero volume and zero return on these days. Second, stocks with higher transaction costs have less private information acquisition because of the higher transaction costs which gives traders a low incentive to obtain private information. Thus, even on positive volume days, these illiquid stocks can experience no-information-revelation and therefore zero return on these days. ${ }^{26}$ Thus:

$$
\text { Zeros }=\frac{\text { Number of days with zero returns }}{\text { Total number of days in the subsample }}
$$

Amihud $^{27}$ develops a price impact measure which can be interpreted as the daily stock price response to one dollar of trading volume. Specifically, he uses the following Illiquidity ratio:

$$
\text { Illiquidity }=\frac{1}{T} \sum_{t=0}^{T} \frac{\left|r_{t}\right|}{\text { Volume }_{t}}
$$

where $r_{t}$ is the return on day $t$ and Volume $e_{t}$ is the dollar volume on day $t$. The average is calculated over only the positive volume days in the subsample since the ratio is undefined for zero volume days. This measure has been widely used by many ${ }^{28}$ to examine liquidity.

\section{B. Analysis of RM and IPO Liquidity}

In tables 6 and 7, we report median liquidity measures for various samples of our data. Again, we use medians rather than means because of the skewness found in our sample, and we report the Wilcoxon zstatistic for various differences in medians.

In Panel A of Table 6, we look at liquidity for RMs from the RM event date to six months after the 
event date, the "lock-up period," and compare this sample to RMs from the RM announcement date to the RM event date, the "pre-event period.” We find that the share turnover ratio is lower during the typical lock-up period than during the pre-event period. This supports the idea, which will be discussed further below, that locked-up shares form a significant portion of trading volume; thus, during the lock-up period, trading volume is less than during other periods. We also find that Zeros is smaller during the lock-up period relative to the pre-event period. This suggests that, although normalized trading volume is lower during the lock-up period, the price-impact of trades is smaller. Although not statistically significant, Volatility is also smaller during the lock-up period. Part of this result could be driven by the fact that RMs can be withdrawn after they are initially announced.

In Panel B of Table 6, we look at liquidity for RMs for the lock-up period and compare the lock-up period, from the RM event date through six months thereafter, to the post lock-up period, from seven months to 12 months though 12 months after the RM event date. We find that Zeros are higher and that Illiquidity is lower during the lock-up period than in the post lock-up period. This accords with the idea that lock-up shares are a significant part of trading volume and that during the lock-up period price impacts of trade are larger due to there being more asymmetric information in the market.

In Panel A of Figure11, we compare RMs during the lock-up period to IPOs during the lock-up period. We find that the Turnover is lower whereas Volatility and Illiquidity are higher. IPOs tend to be more liquid than RMs during the lock-up period, likely due to underwriter support for IPOs. Panels B and C of Table 7 compare RMs after the lock-up period and IPOs during the six-month lock-up period to the six-month post lock-up period, respectively. None of the differences in these comparisons is statistically significant.

In Figure 12, we show the coefficients from univariate regressions using CAR windows for RM announcement dates (Panel A), RM event dates (Panel B), and IPOs by issue date (Panel C) as the dependent variable. The explanatory variable in each regression is the liquidity variable listed in each row. Our main finding is that both Turnover and Volatility have positive and significant coefficients for 
RMs and IPOs. Purely from the perspective of liquidity, this is somewhat puzzling, since higher turnover indicates higher liquidity, which theoretically should be associated with a lower risk premium. ${ }^{29}$ However, these results seem consistent with the "analyst-hype” hypothesis, which predicts that successful going-public events generate greater analyst coverage, higher turnover, and more favorable stock returns. ${ }^{30}$ We also find that Zeros and Illiquidity have negative and significant coefficients for IPO firms, a result that again can be interpreted as being consistent with the analyst-hype hypothesis. However, these two variables have positive coefficients for RMs in the prior-event-day window, a result that may have less to do with hype and more to do with liquidity risk.

\section{Conclusion}

We examine RMs in the biotechnology industry and find that, when compared to IPOs, RMs are smaller, have significantly lower market valuations relative to size, and generally invest less. We also find that RMs exhibit positive abnormal returns on the announcement date and throughout the first year after the RM event, a result that is amplified by real firm-level investment. In looking at liquidity measures, we find that RMs are generally less liquid than IPOs, and that illiquidity is greater during the six-month lockup period following the RM event. We find supporting evidence among RMs for the analyst-hype hypothesis and a liquidity risk premium.

These findings suggest that RMs provide an important and value-increasing option for biotech firms to access capital markets. Although investors seem to have been cautious in their initial valuations of biotech RMs, overcoming reservations with respect to asymmetric information problems and illiquidity risk, they have been handsomely rewarded. Thus, RMs may be an appropriate alternative financing vehicle in capital intensive, high-risk biotechnology companies which require accessing deeper and larger pools of investors in public capital markets across multiple milestone periods in a "pay for progress" real options framework. 
Table 1. Financial Characteristics

This table reports median values for financial variables of reverse mergers (RMs) and initial public offerings (IPOs). The comparison focuses on size and productivity (Panel A), financial health (Panel B), and investment variables (Panel C). Free cash flow $(F C F)$ is defined as EBIT minus taxes, plus depreciation and amortization, minus change in working capital and change in other assets. All variables except employees are in millions of dollars. All variables are measured on the most adjacent annual report day following the event date for RMs and following the issue day for IPOs. The table reports median values for each variable. Wilcoxon z-test statistics are reported for differences in medians. The symbols *, $* *$, and $* * *$ denote statistical significance at the $0.10,0.05$, and 0.01 levels, respectively. Our sample period is from 2000 to 2009 . 
Panel A: Size and Productivity

\begin{tabular}{lcccc}
\hline & $\begin{array}{c}\text { Biotech } \\
\text { RMs }\end{array}$ & Biotcech & Difference in & Wilcoxon \\
& Median & IPOs Median & Medians & z-statistic \\
\hline Total Assets (TA) & 51.41 & 86.26 & -34.85 & 0.0002 \\
Sales & 3.25 & 4.73 & -1.48 & 0.3968 \\
Employees & 68.5 & 90 & -21.50 & $0.0262 \quad * *$ \\
Mkt Cap & 13.30 & 274.79 & -261.49 & $<.0001$ \\
Sales / TA & $12.01 \%$ & $5.97 \%$ & $6.04 \%$ & 0.1773 \\
Book Equity / Mkt Cap & $91.56 \%$ & $24.67 \%$ & $66.89 \%$ & $<.0001 * * *$ \\
Sales / Mkt Cap & $23.95 \%$ & $1.95 \%$ & $21.99 \%$ & $0.0001 * * *$ \\
Mkt Cap / Employees & $60.05 \%$ & $258.15 \%$ & $-198.10 \%$ & $<.0001 * * *$ \\
TA / Employees & $67.47 \%$ & $89.01 \%$ & $-21.54 \%$ & 0.1007 \\
\hline
\end{tabular}

Panel B: Financial Health

\begin{tabular}{lcccc}
\hline \multicolumn{1}{c}{ Variable } & $\begin{array}{c}\text { Biotech } \\
\text { RMs }\end{array}$ & $\begin{array}{c}\text { Biotcech } \\
\text { IPOs Median }\end{array}$ & $\begin{array}{c}\text { Difference in } \\
\text { Medians }\end{array}$ & $\begin{array}{c}\text { Wilcoxon } \\
\text { Z-statistic }\end{array}$ \\
\hline Current Liabilities / TA & $17.78 \%$ & $11.91 \%$ & $5.87 \%$ & 0.0008 \\
Current Liabilities / Sales & $101.72 \%$ & $83.67 \%$ & $18.05 \%$ & 0.4176 \\
Current Liabilities / Employees & $14.40 \%$ & $9.42 \%$ & $4.98 \%$ & $0.0272 * *$ \\
Current Liabilities / Mkt Cap & $34.68 \%$ & $4.06 \%$ & $30.63 \%$ & $<.0001 * * *$ \\
Long-term Debt / TA & $0.71 \%$ & $0.83 \%$ & $-0.12 \%$ & 0.4281 \\
Long-term Debt / Sales & $5.73 \%$ & $18.36 \%$ & $-12.63 \%$ & 0.2044 \\
Long-term Debt / Employees & $0.31 \%$ & $0.93 \%$ & $-0.62 \%$ & 0.2761 \\
Long-term Debt / Mkt Cap & $2.54 \%$ & $0.23 \%$ & $2.31 \%$ & 0.1049 \\
FCF / TA & $-87.85 \%$ & $-88.23 \%$ & $0.37 \%$ & 0.1879 \\
FCF / Sales & $-307.65 \%$ & $-747.25 \%$ & $439.59 \%$ & $0.0263 * *$ \\
FCF / Employees & $-53.92 \%$ & $-71.10 \%$ & $17.18 \%$ & $0.0518 *$ \\
FCF / Mkt Cap & $-43.63 \%$ & $-27.13 \%$ & $-16.51 \%$ & 0.2539 \\
\hline
\end{tabular}

Panel C: Investment

\begin{tabular}{lcccc}
\hline & Biotech & & & \\
& RMs & Biotcech & Difference in & Wilcoxon \\
& Vedian & IPOs Median & Medians & z-statistic \\
\hline R\&D / TA & $24.27 \%$ & $31.04 \%$ & $-6.77 \%$ & 0.2359 \\
R\&D / Sales & $162.81 \%$ & $260.54 \%$ & $-97.73 \%$ & $0.0678 *$ \\
R\&D / Employees & $29.57 \%$ & $24.25 \%$ & $5.32 \%$ & 0.3533 \\
R\&D / Mkt Cap & $63.10 \%$ & $8.60 \%$ & $54.51 \%$ & $<.0001^{* * *}$ \\
CAPX / TA & $1.20 \%$ & $1.90 \%$ & $-0.71 \%$ & $0.0024^{* * *}$ \\
CAPX / Sales & $5.40 \%$ & $19.33 \%$ & $-13.94 \%$ & $0.0004^{* * *}$ \\
CAPX / Employees & $0.78 \%$ & $1.49 \%$ & $-0.71 \%$ & $<.0001^{* * *}$ \\
CAPX / Mkt Cap & $1.24 \%$ & $0.59 \%$ & $0.64 \%$ & $0.0009 * *$ \\
\hline
\end{tabular}


Table 2. Cumulative Abnormal Returns

Panel A reports the cumulative abnormal returns (CARs) for various event windows surrounding the announcement date of reverse mergers (RMs). Event windows are defined in terms of trading days. Panel B reports the CARs for event windows surrounding the event date of RMs. We split the long-term 1-year window into two 6 month periods according to the typical lock-up periods following the RM event date. Panel C reports the CARs for event windows after the issue date of IPOs. We again split the long-term 1-year window into two due to the typical lock-up period following an IPO. The abnormal returns are calculated by subtracting the CRSP value-weighted index returns from daily raw returns. The CAR test statistic is based upon Patell's Z test. The symbols *, **, and *** denote statistical significance at the $0.10,0.05$, and 0.01 levels, respectively. Our sample period is from 2000 to 2009.

Panel A: RMs by Announcement Date

\begin{tabular}{lrr}
\hline Event window & \multicolumn{1}{l}{ CAR } & Patell Z \\
\hline$(-21,-2)$ & $-2.03 \%$ & -0.424 \\
$(-1,-1)$ & $1.97 \%$ & 0.719 \\
$(0,0)$ & $23.43 \%$ & 10.541 \\
$(0,+21)$ & $32.52 \%$ & 3.003 \\
$(0,+126)$ & $38.91 \%$ & 2.061 \\
$* *$ \\
$(0,+252)$ & $58.97 \%$ & 2.002
\end{tabular}${ }^{* *}$

Panel B: RMs by Event Date

\begin{tabular}{lrc}
\hline Event window & \multicolumn{1}{c}{ CAR } & t-stat \\
\hline$(-21,-2)$ & $7.07 \%$ & 0.958 \\
$(-1,-1)$ & $10.48 \%$ & 3.928 \\
$(0,0)$ & $-0.39 \%$ & -0.533 \\
$(0,+21)$ & $-12.49 \%$ & -2.668 \\
$(0,+126)$ & $-2.46 \%$ & -0.796 \\
$(+127,+252)$ & $15.14 \%$ & 0.969 \\
\hline
\end{tabular}

Panel C: IPOs

\begin{tabular}{lcc}
\hline Event window & CAR & Patell Z \\
\hline$(0,0)$ & $3.51 \%$ & 3.064 \\
$(0,+21)$ & $2.96 \%$ & 0.257 \\
$(0,+126)$ & $1.41 \%$ & -0.083 \\
$(+127,+252)$ & $5.13 \%$ & 1.532
\end{tabular} *


Table 3. Multivariate CAR Regressions by RM Announcement Date

This table reports multivariate regression coefficients where the dependent variable is cumulative abnormal returns (CARs) for various event windows surrounding the announcement date of reverse mergers (RMs), measured in days, as labeled for each column. The independent variables are displayed in the rows of each panel. Abnormal returns are calculated by subtracting the CRSP value-weighted index returns from daily raw returns. The symbols *, **, and *** denote statistical significance at the 0.10, 0.05, and 0.01 levels, respectively. Our sample period is from 2000 to 2009.

Panel A: Financial Health and Total Assets

\begin{tabular}{lrrrr}
\hline & $(0,0)$ & $(0,+21)$ & $(0,+126)$ & $(0,+252)$ \\
\hline Log(TA) & -0.02 & -0.09 & 0.04 & 0.09 \\
Current Liabilities / TA & 0.00 & 0.38 & 1.39 & 2.65 \\
Long-term Debt / TA & -0.01 & -0.22 & -0.45 & -1.41 \\
FCF / TA & 0.01 & 0.04 & 0.07 & 0.28 \\
\hline
\end{tabular}

Panel B: Investment and Total Assets

\begin{tabular}{lrrrr}
\hline & $(0,0)$ & $(0,+21)$ & $(0,+126)$ & $(0,+252)$ \\
\hline Log(TA) & -0.04 & -0.13 & -0.14 & -0.28 \\
CAPX / TA & 5.42 & 18.17 & 19.99 & 35.28 \\
R\&D / TA & $1.11^{* *}$ & $1.01^{*}$ & 0.51 & 0.00 \\
\hline
\end{tabular}

Panel C: Financial Health and Market Capitalization

\begin{tabular}{lrrrc}
\hline & $(0,0)$ & $(0,+21)$ & $(0,+126)$ & $(0,+252)$ \\
\hline Log(Mkt Cap) & -0.01 & -0.08 & -0.01 & 0.05 \\
Current Liabilities / Mkt Cap & 0.01 & 0.11 & $0.48 * *$ & $1.35^{* * *}$ \\
Long-term Debt / Mkt Cap & -0.03 & -0.10 & -0.11 & $-0.73^{* *}$ \\
FCF / Mkt Cap & 0.04 & 0.07 & -0.11 & 0.01 \\
\hline
\end{tabular}

Panel D: Investment and Market Capitalization

\begin{tabular}{lcccc}
\hline & $(0,0)$ & $(0,+21)$ & $(0,+126)$ & $(0,+252)$ \\
\hline Log(Mkt Cap) & -0.03 & -0.07 & -0.11 & -0.20 \\
CAPX / Mkt Cap & 0.18 & 1.66 & 2.39 & $5.11^{* *}$ \\
R\&D / Mkt Cap & $0.80^{* * *}$ & $0.77 * * *$ & $0.69 * * *$ & $0.50^{*}$ \\
\hline
\end{tabular}




\section{Table 4. Multivariate CAR Regressions by RM Event Date}

This table reports multivariate regression coefficients where the dependent variable is cumulative abnormal returns (CARs) for various event windows surrounding the reverse merger event date, measured in days, as labeled for each column. The independent variables are displayed in the rows of each panel. Abnormal returns are calculated by subtracting the CRSP value-weighted index returns from daily raw returns. The symbols *, **, and *** denote statistical significance at the 0.10 , 0.05, and 0.01 levels, respectively. Our sample period is from 2000 to 2009.

Panel A: Financial Health and Total Assets

\begin{tabular}{lccrrr}
\hline & $(-1,-1)$ & $(0,0)$ & $(0,+21)$ & $(0,+126)$ & $(+127,+252)$ \\
\hline Log(TA) & 0.00 & 0.01 & -0.06 & 0.11 & 0.03 \\
Current Liabilities / TA & -0.04 & 0.06 & 0.94 & 2.02 & -0.99 \\
Long-term Debt / TA & $0.79 * *$ & 0.02 & -0.83 & -1.54 & 0.16 \\
FCF / TA & -0.02 & -0.02 & 0.19 & 0.25 & -0.03 \\
\hline
\end{tabular}

Panel B: Investment and Total Assets

\begin{tabular}{lccccc}
\hline & $(-1,-1)$ & $(0,0)$ & $(0,+21)$ & $(0,+126)$ & $(+127,+252)$ \\
\hline Log(TA) & $-0.11 *$ & 0.00 & -0.04 & -0.06 & -0.20 \\
CAPX / TA & -0.57 & -1.39 & $13.98 * * *$ & $18.67 *$ & $-16.17 *$ \\
R\&D / TA & $-0.38 *$ & 0.00 & 0.05 & -0.49 & -0.50 \\
\hline
\end{tabular}

Panel C: Financial Health and Market Capitalization

\begin{tabular}{lcccrc}
\hline & $(-1,-1)$ & $(0,0)$ & $(0,+21)$ & $(0,+126)$ & $(+127,+252)$ \\
\hline Log(Mkt Cap) & 0.01 & 0.01 & -0.03 & 0.06 & -0.03 \\
Current Liabilities / Mkt Cap & $0.13^{* *}$ & 0.00 & $0.43 * *$ & $0.93 * * *$ & -0.23 \\
Long-term Debt / Mkt Cap & $0.20^{* * *}$ & 0.01 & $-0.41 * * *$ & $-0.72 * * *$ & -0.25 \\
FCF / Mkt Cap & $-0.05^{*}$ & 0.02 & $0.16 * *$ & 0.16 & -0.10 \\
\hline
\end{tabular}

Panel D: Investment and Market Capitalization

\begin{tabular}{lccccc}
\hline & $(-1,-1)$ & $(0,0)$ & $(0,+21)$ & $(0,+126)$ & $(+127,+252)$ \\
\hline Log(Mkt Cap) & $-0.11 *$ & 0.00 & 0.01 & -0.01 & -0.14 \\
CAPX / Mkt Cap & -0.07 & -0.19 & $2.18 * * *$ & $3.23 * *$ & -1.87 \\
R\&D / Mkt Cap & -0.13 & 0.02 & 0.00 & -0.22 & -0.13 \\
\hline
\end{tabular}




\section{Table 5. Multivariate CAR Regressions by IPO Issue Date}

This table reports multivariate regression coefficients where the dependent variable is cumulative abnormal returns (CARs) for various event windows surrounding the IPO issue date, measured in days, as labeled for each column. The independent variables are displayed in the rows of each panel. Abnormal returns are calculated by subtracting the CRSP value-weighted index returns from daily raw returns. The symbols *, **, and *** denote statistical significance at the $0.10,0.05$, and 0.01 levels, respectively. Our sample period is from 2000 to 2009.

Panel A: Financial Health and Total Assets

\begin{tabular}{lccrc}
\hline & $(0,0)$ & $(0,+21)$ & $(0,+126)$ & $(+127,+252)$ \\
\hline Log(TA) & -0.01 & 0.07 & 0.03 & -0.07 \\
Current Liabilities / TA & $0.89 * *$ & $0.01 * *$ & 0.05 & -0.09 \\
Long-term Debt / TA & -0.61 & -0.04 & -0.25 & -0.16 \\
FCF / TA & -0.03 & -0.06 & 0.08 & 0.19 \\
\hline
\end{tabular}

Panel B: Investment and Total Assets

\begin{tabular}{lcrrr}
\hline & $(0,0)$ & $(0,+21)$ & $(0,+126)$ & $(+127,+252)$ \\
\hline Log(TA) & -0.01 & $0.06 *$ & 0.03 & -0.05 \\
CAPX / TA & 0.30 & 0.41 & 0.25 & 0.39 \\
R\&D / TA & $0.29 * *$ & 0.03 & 0.11 & -0.15 \\
\hline
\end{tabular}

Panel C: Financial Health and Market Capitalization

\begin{tabular}{lrrrr}
\hline & $(0,0)$ & $(0,+21)$ & $(0,+126)$ & $(+127,+252)$ \\
\hline Log(Mkt Cap) & 0.00 & $0.08 * *$ & 0.02 & -0.03 \\
Current Liabilities / Mkt Cap & 1.68 & 0.24 & 0.27 & 1.13 \\
Long-term Debt / Mkt Cap & -1.74 & -0.25 & -0.53 & -0.46 \\
FCF / Mkt Cap & 0.01 & $-0.32 * *$ & -0.36 & 0.15 \\
\hline
\end{tabular}

Panel D: Investment and Market Capitalization

\begin{tabular}{lccrr}
\hline & $(0,0)$ & $(0,+21)$ & $(0,+126)$ & $(+127,+252)$ \\
\hline Log(Mkt Cap) & 0.01 & $0.05 *$ & -0.30 & -0.09 \\
CAPX / Mkt Cap & 0.53 & 1.10 & 0.72 & -0.26 \\
R\&D / Mkt Cap & 0.61 & 0.28 & 0.25 & -0.83 \\
\hline
\end{tabular}




\section{Table 6. Liquidity Measures: Before and After the RM Event Date}

This table compares liquidity of stock trading activity for RMs and IPOs across two periods. In Panel A, the period is from the RM announcement date to the RM event date, the period when RM news has become public but the deal is not consummated yet. In Panel B, the period is the typical 6-month lock-up period after the RM event date. Turnover is defined as the daily number of share-trading volume divided by the number of common shares outstanding, and then the daily ratios are averaged over time. Volatility is defined as the standard deviation of daily returns, multiplied by the square root of 252 . Zeros is the proportion of trading days with a zero price change from the previous day over a specified time period.

Illiquidity is the Amihud (2002) measure defined by dividing the absolute daily return by daily dollar trading volume, and then averaging over time. The table reports median values for each measure. Wilcoxon z-test statistics are reported for differences in medians. The symbols $*, * *$, and $* * *$ denote statistical significance at the $0.10,0.05$, and 0.01 levels, respectively. Our sample period is from 2000 to 2009.

Panel A: RMs, Before v. After Event Date

\begin{tabular}{lcccc}
\hline & $\begin{array}{c}\text { RM lock-up } \\
\text { period }\end{array}$ & $\begin{array}{c}\text { RM pre-event } \\
\text { period }\end{array}$ & $\begin{array}{c}\text { Difference } \\
\text { in medians }\end{array}$ & $\begin{array}{c}\text { Wilcoxon } \\
\text { z-statistic }\end{array}$ \\
\hline Turnover & $0.25 \%$ & $0.54 \%$ & $-0.29 \%$ & 0.0108 \\
Volatility & $89.48 \%$ & $113.74 \%$ & $-24.27 \%$ & 0.3606 \\
Zeros & $4.43 \%$ & $8.51 \%$ & $-4.08 \%$ & 0.0053 \\
Illiquidity & $76.05 \%$ & $107.57 \%$ & $-31.52 \%$ & 0.2463 \\
\hline
\end{tabular}

Panel B: RMs, Before v. After Lock-Up

\begin{tabular}{lcccc}
\hline & $\begin{array}{c}\text { RM lock-up } \\
\text { period }\end{array}$ & $\begin{array}{c}\text { RM post lock- } \\
\text { up period }\end{array}$ & $\begin{array}{c}\text { Difference } \\
\text { in medians }\end{array}$ & $\begin{array}{c}\text { Wilcoxon } \\
\text { z-statistic }\end{array}$ \\
\hline Turnover & $0.25 \%$ & $0.46 \%$ & $-0.20 \%$ & 0.1233 \\
Volatility & $89.48 \%$ & $82.23 \%$ & $7.24 \%$ & 0.2956 \\
Zeros & $4.43 \%$ & $2.38 \%$ & $2.05 \%$ & $0.0525 *$ \\
Illiquidity & $76.05 \%$ & $17.26 \%$ & $58.78 \%$ & 0.0696
\end{tabular} *


Table 7. Liquidity Measures: RMs vs. IPOs

This table compares liquidity of stock trading activity for RMs and IPOs. In Panel A, we compare RMs to IPOs during the typical 6-month lock-up period after the RM event date or IPO issue date. In Panel B, we compare RMs to IPOs during the 6-month period after the lock-up period. In Panel C, we compare IPOs during first 6-month period after the IPO issue date and the second 6-month after that. Turnover is defined as the daily number of share-trading volume divided by the number of common shares outstanding, and then the daily ratios are averaged over time. Volatility is defined as the standard deviation of daily returns, multiplied by the square root of 252. Zeros is the proportion of trading days with a zero price change from the previous day over a specified time period. Illiquidity is the Amihud (2002) measure defined by dividing the absolute daily return by daily dollar trading volume, and then averaging over time. The table reports median values for each measure. Wilcoxon z-test statistics are reported for differences in medians. The symbols *, **, and *** denote statistical significance at the 0.10, 0.05, and 0.01 levels, respectively. Our sample period is from 2000 to 2009.

Panel A: RMs v. IPOs During Lock-Up

\begin{tabular}{lcccc}
\hline Variable & $\begin{array}{c}\text { RM Lock-up } \\
\text { period }\end{array}$ & $\begin{array}{c}\text { IPO lock-up } \\
\text { period }\end{array}$ & $\begin{array}{c}\text { Difference } \\
\text { in medians }\end{array}$ & $\begin{array}{c}\text { Wilcoxon } \\
\text { z-statistic }\end{array}$ \\
\hline Turnover & $0.25 \%$ & $0.43 \%$ & $-0.17 \%$ & 0.0389 \\
Volatility & $89.48 \%$ & $71.76 \%$ & $17.72 \%$ & 0.0136 \\
Zeros & $4.43 \%$ & $4.03 \%$ & $0.40 \%$ & 0.4025 \\
Illiquidity & $76.05 \%$ & $8.53 \%$ & $67.52 \%$ & 0.0001
\end{tabular}$* * *$

Panel B: RMs v. IPOs, After Lock-Up

\begin{tabular}{lcccc}
\hline & $\begin{array}{c}\text { RM post lock- } \\
\text { up period }\end{array}$ & $\begin{array}{c}\text { IPO post lock- } \\
\text { up period }\end{array}$ & $\begin{array}{c}\text { Difference } \\
\text { in medians }\end{array}$ & $\begin{array}{c}\text { Wilcoxon } \\
\text { z-statistic }\end{array}$ \\
\hline Turnover & $0.46 \%$ & $0.43 \%$ & $0.03 \%$ & 0.2875 \\
Volatility & $82.23 \%$ & $72.81 \%$ & $9.42 \%$ & 0.0388 \\
Zeros & $2.38 \%$ & $3.86 \%$ & $-1.48 \%$ & 0.1164 \\
Illiquidity & $17.26 \%$ & $9.13 \%$ & $8.13 \%$ & 0.0487
\end{tabular}${ }^{* *}$

Panel C: IPOs, Before and After Lock-Up

\begin{tabular}{lcccc}
\hline Variable & $\begin{array}{c}\text { IPO lock-up } \\
\text { period }\end{array}$ & $\begin{array}{c}\text { IPO post lock- } \\
\text { up period }\end{array}$ & $\begin{array}{c}\text { Difference } \\
\text { in medians }\end{array}$ & $\begin{array}{c}\text { Wilcoxon } \\
\text { z-statistic }\end{array}$ \\
\hline Turnover & $0.43 \%$ & $0.43 \%$ & $0.00 \%$ & 0.1265 \\
Volatility & $71.76 \%$ & $72.81 \%$ & $-1.05 \%$ & 0.4333 \\
Zeros & $4.03 \%$ & $3.86 \%$ & $0.17 \%$ & 0.0080 \\
Illiquidity & $8.53 \%$ & $9.13 \%$ & $-0.60 \%$ & 0.2260 \\
\hline
\end{tabular}


Table 8. Liquidity and CARs

This table reports univariate regression coefficients where the dependent variable is cumulative abnormal returns (CARs) for various event windows surrounding the reverse merger announcement date (Panel A) and event date (Panel B), and IPO issue date (Panel C), measured in days, as labeled for each column. The independent variables are displayed in the rows of each panel. Abnormal returns are calculated by subtracting the CRSP value-weighted index returns from daily raw returns. The symbols *, **, and *** denote statistical significance at the $0.10,0.05$, and 0.01 levels, respectively. Our sample period is from 2000 to 2009.

Panel A: RMs by Announcement Date

\begin{tabular}{lcccrr}
\hline & $(-1,-1)$ & $(0,0)$ & $(0,+21)$ & $(0,+126)$ & $(0,+252)$ \\
\hline Turnover & 0.02 & $3.92 * * *$ & $32.64 * * *$ & $122.58 * * *$ & $161.10^{* * *}$ \\
Volatility & $0.03^{*}$ & $1.07^{* * *}$ & $0.31^{* * *}$ & $0.59 * * *$ & $0.79 * * *$ \\
Zeros & 0.04 & -2.59 & -2.43 & -1.07 & 2.33 \\
Illiquidity & $0.02 * * *$ & 0.00 & 0.02 & 0.02 & $0.11 * *$ \\
\hline
\end{tabular}

Panel B: RMs by Event Date

\begin{tabular}{lccccc}
\hline & $(-1,-1)$ & $(0,0)$ & $(0,+21)$ & $(0,+126)$ & $(+127,+252)$ \\
\hline Turnover & $17.17^{* * *}$ & 1.40 & 6.64 & $81.08 * * *$ & $108.69 * * *$ \\
Volatility & 0.01 & $0.02 *$ & 0.03 & 0.40 & $0.78 *$ \\
Zeros & $3.11^{* * *}$ & -0.08 & 0.81 & 1.66 & $5.83 * *$ \\
Illiquidity & 0.00 & 0.00 & -0.01 & -0.02 & 0.05 \\
\hline
\end{tabular}

Panel C: IPOs

\begin{tabular}{lrrccc}
\hline & $(-1,-1)$ & $(0,0)$ & $(0,+21)$ & $(0,+126)$ & $(+127,+252)$ \\
\hline Turnover & N/A & 0.10 & 0.54 & $7.61 * * *$ & $37.51 * * *$ \\
Volatility & N/A & 0.02 & $0.18 * * *$ & 0.19 & $0.51 * * *$ \\
Zeros & N/A & -0.25 & -0.09 & $-4.99 * * *$ & $-3.21 * *$ \\
Illiquidity & N/A & 0.03 & -0.21 & 0.00 & $-0.05 * *$ \\
\hline
\end{tabular}


Figure 1: Start-Up Biofinancing Continuum

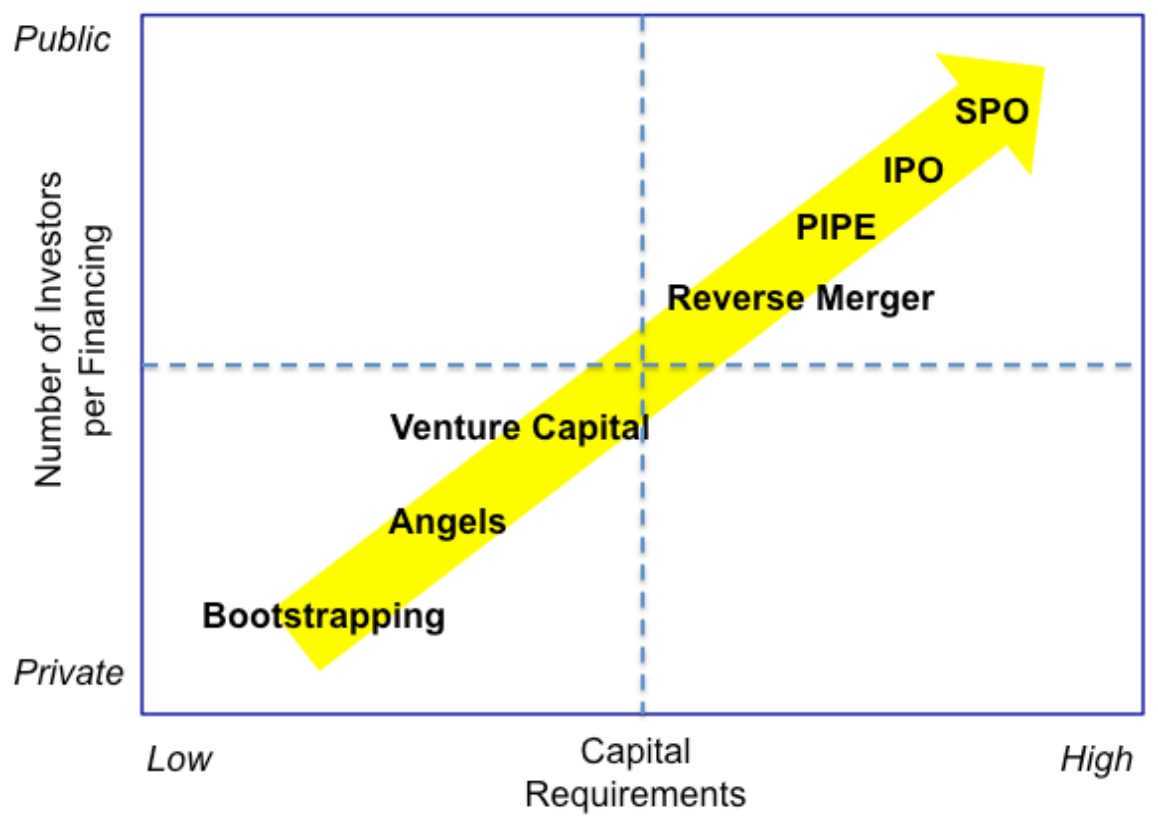


Figure 2: Biotechnology IPOs 1994-2010

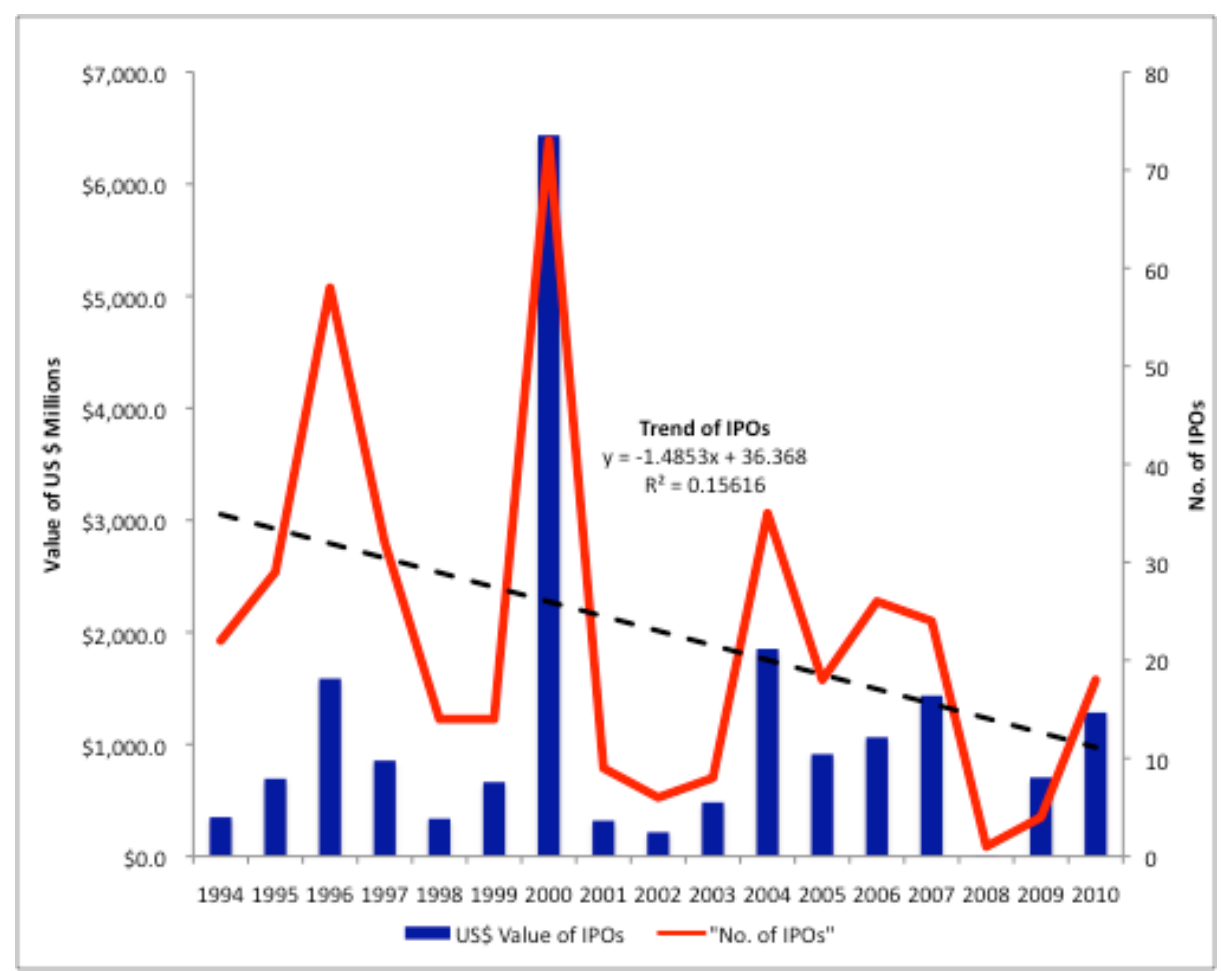


Figure 3: Biotechnology Reverse Mergers: 2000-2009

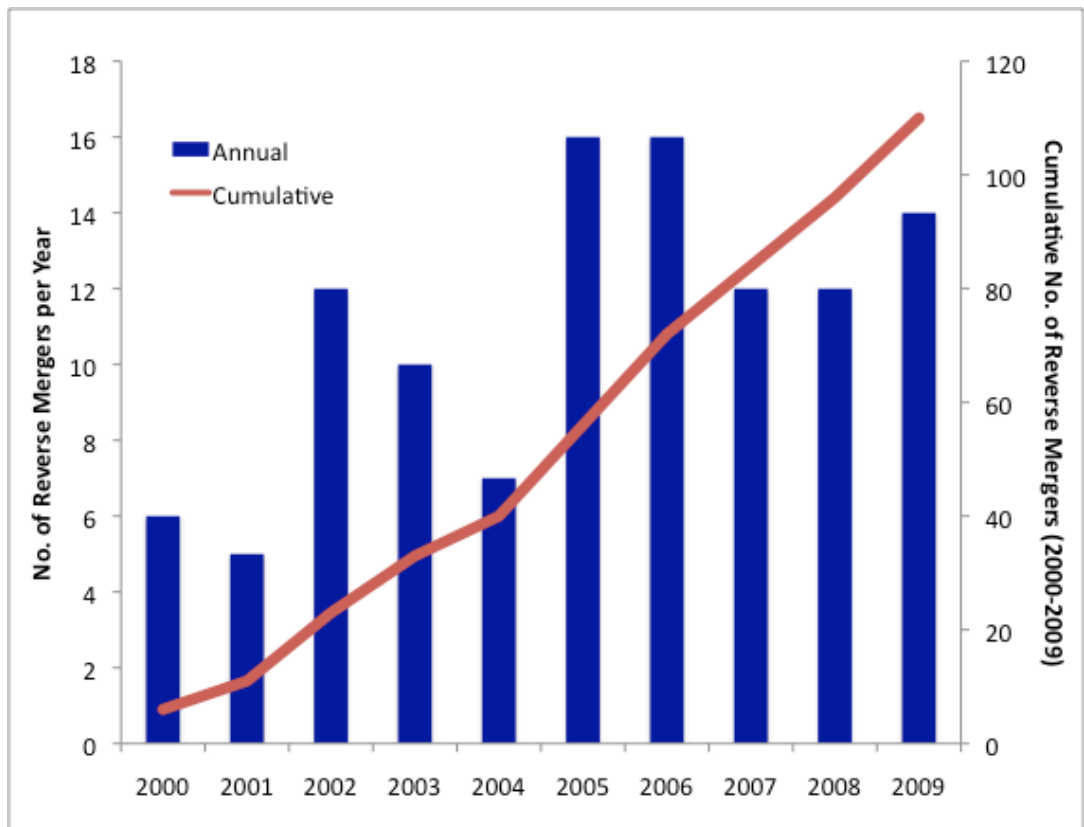


Figure 4: Cumulative Abnormal Returns

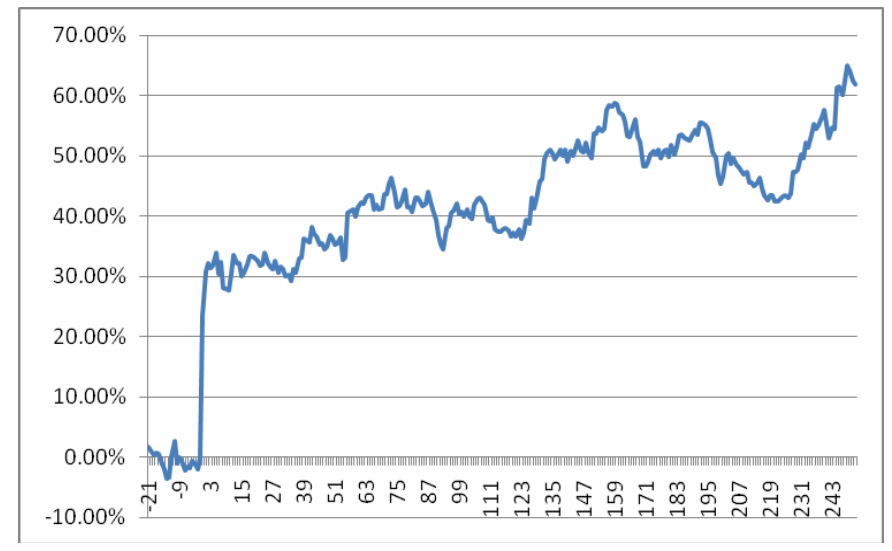

RMs by Announcement Date

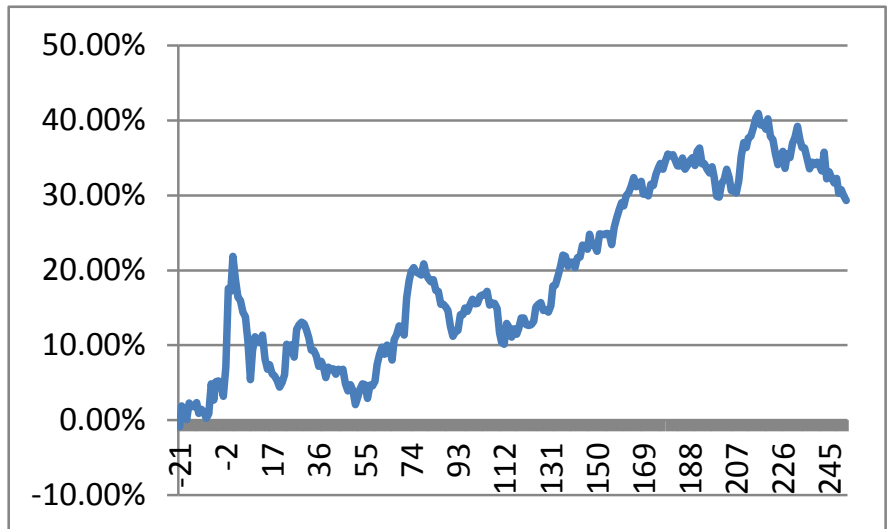

RMs by Event Date

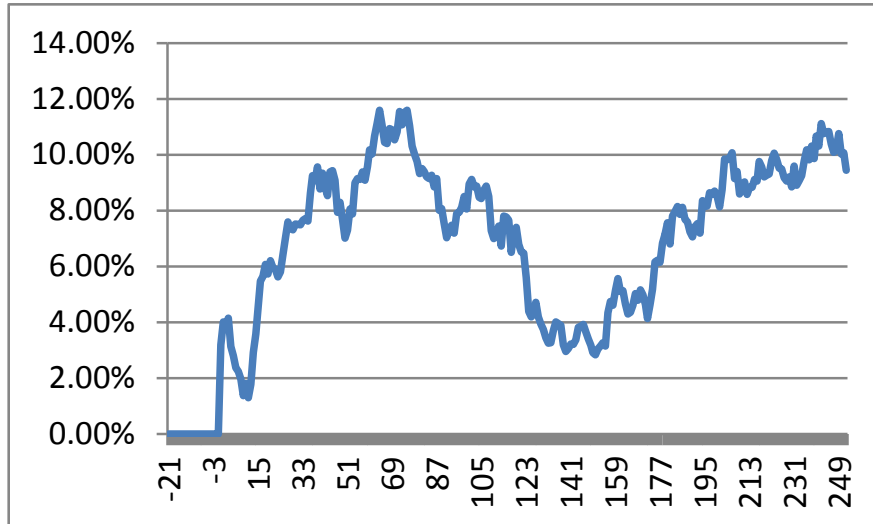

IPOs 


\section{Reference}

1 Christensen, C, Overdorf, M, "Meeting the Challenge of Disruptive Change," Harvard Business Review, 78, 66-76 (2000); Brekke, OH, Sandlie, I, “Therapeutic Antibodies for Human Diseases at the Dawn of the Twenty-First Century,” Nature Review of Drug Discovery, 2, 52-62 (2003); Pera, MF, Trounson, AO, "Human Embryonic Stem Cells: Prospects for Development,” Development, 131, 5515-25 (2004); Stylios, GK, Giannoudis, PV, Wan, T, “Applications of Nanotechnologies in Medical Practice,” Injury, 36, S6-S13 (2005).

2 Zimmerman, MA, Deeds, DL, “Legitimacy and the Initial Public Offerings of Biotechnology Firms," Frontiers for Entrepreneurship Research, 1987, available at www.babson.edu/entrep/fer/papers97; Deeds, DL, Decarolis, D, Coombs, JE, "The Impact of Firm-Specific Capabilities on the Amount of Capital Raised in an Initial Public Offering: Evidence from the Biotechnology Industry,” Journal of Business Venturing, 12, 31-46 (1997); George, G, Kotha, R, Zheng, Y "Entry into Insular Domains: A Longitudinal Study of Knowledge Structuration and Innovation in Biotechnology Firms,” Journal of Management Studies, 45, 1448-1474 (2008); Ahn, M, Davenport, S, Meeks, M, Bednarek, R "Exploring Technology Agglomeration Patterns for Multinational Pharmaceutical and Biotechnology Firms,” Journal of Commercial Biotechnology, 16: 17-32 (2009).

3 Laurie, D, Doz, Y, Sheer, C, “Creating New Growth Platforms,” Harvard Business Review, 84, 80-90 (2006).

4 Stinchcombe, AL, “Organizations and Social Structure” in March, JG (Ed.), Handbook of Organizations, Chicago: Rand-McNally (1965); Singh, J, Tucker, D, House, “Organizational Legitimacy and the Liability of Newness,” Administrative Science Quarterly, 31, 171-193 (1986); Hannan, MT, Carroll, GR, Dynamics of Organizational Populations: Density, Legitimation, and Competition, New York; Oxford: Oxford University Press (1992); Aldrich, HE, Fiol, CM "Fools Rush In? The Institutional Context of Industry Creation,” Academy of Management Review, 19, 645-670 (1994); Ruef, M, Scott, WR, “A Multidimensional Model of Organizational Legitimacy: Hospital Survival in Changing Institutional Environments,” Administrative Science Quarterly, 43(4): 877-904 (1998).

5 Aldrich, Fiol, supra, n.4.; Rao, RS, Chandy, RK, Prabhu, JC “The Fruits of Legitimacy: Why Some New Ventures Gain More from Innovation Than Others,” Journal of Marketing, 72, 58-75 (2008).

6 Morgan Jr, IW, Abetti, PA, "Private and Public 'Cradle to Maturity' Financing Patterns of U.S. Biotech Ventures (1970-2001),” Journal of Private Equity, Spring, 9-25 (2004); Adjei, F, Cyree, KB, Walker, MM, "The Determinants and Survival of Reverse Mergers vs IPOs," Journal of Economics and Finance, 32, 176-194 (2008).

7 Banerjee, PM, “Financing as Mother's Milk for Internaional Biotechnology Start-Ups,” International Journal of Technoentrepreneurship, 2, 1, 45-63, p. 45 (2009).

8 BIO (Biotechnology Industry Organization), “BIO 2005-2006: Guide to biotechnology,” Washington DC: BIO (2007).

9 Ernst \& Young (2006) “Beyond Borders: A Global Perspective,” EYGM Limited, available at www.ey.com.

10 Ahn, M, Meeks, M, "Building a Conducive Environment for Life Science-Based Entrepreneurship and Industry Clusters,” Journal of Commercial Biotechnology, 14, 20-30 (2007); Tufts (The Tufts Centre for the Study of Drug Development), "Structuring Clinical Organization to Improve R\&D Productivity," available at www.csdd.tufts.edu (2007).

11 Pisano, G, “Can Science Be a Business?” Harvard Business Review, 10, 1-12, (2006).

${ }^{12}$ Kellogg, D, Charnes, JM, “Real-Options Valuation for a Biotechnology Company,” Financial Analysts Journal, 56, 3, 76-84 (2000).

13 Deeds, DeCaolis, Coombs, supra, n.2.; Gulati, R, Higgins, MC, "Which Ties Matter When? The Contingent Effects of Interorganizal Partnerships on IPO Success,” Strategic Management Journal, 24, 2, 127 144 (2003).

14 Pisano, supra, n.11.

15 Daily, CM, Certo, ST, Dalton, DR, Roengpitya, R, "IPO Underpricing: A Meta-Analysis and Research Synthesis,” Entrepreneurship Theory and Practice, Spring, 271-295 (2003); Purnanandam, AK, Swaminathan, 
B, “Are IPOs Really Underpriced?” The Review of Financial Studies, 17, 3, 811-848 (2004); Demers, E, Joos, P, “IPO Failure Risk,” Journal of Accounting Research, 45, 2, 333-372 (2007); Guo, R, Lev, B, Shi, C, "Explaining the Short- and Long-Term IPO Anomalies in he US by R\&D," Journal of Business Finance and Accounting, 33, 550-579 (2006); Pukthuanthong, K, “Underwriter Learning About Unfamiliar Firms: Evidence from the History of Biotech IPOs,” Journal of Financial Markets, 9, 366-407, (2006).

16 Gulati, Higgins, supra, n.12; Guo, R, Lev, B, Zhou, N, “Competitive Costs of Disclosure by Biotech IPOs,” Journal of Accounting Research, 42, 2, 319-355 (2004); Williams, DR, Duncan, WJ, Ginter, PM, Shewchuk, RM, "Do Governance, Equity Characteristics, and Venture Capital Involvement Affect Long-Term Wealth Creation in US Health Care and Biotechnology IPOs?” Journal of Health Care Finance, 33, 1, 54-71 (2006).

${ }^{17}$ BMO, “Biopharma Data Tables,” BMO Capital Markets Report (2011).

${ }^{18}$ Floros, IV, Sapp, TRA, “Shell Games: On the Value of Shell Companies,” Working Paper, available at www.ssrn.com (2010); Feldman, D, “Reverse Mergers: Taking a Company Public Without an IPO”, Bloomberg Press, New York (2006).

${ }^{19}$ Floros, Sapp, supra, n.18.

20 Arellano-Ostoa, A, Brusco, S, “Understanding Reverse Mergers: A First Approach,” Working Paper, Universidad Carlos III De Madrid (2002); Gleason, KC, Rosenthal, L., Wiggins III, RA, "Backing into Being Public: An Exploratory Analysis of Reverse Takeovers,” Journal of Corporate Finance, 12, 54-79 (2005).

21 Adjei, F, Cyree, KB, Walker, MM, “The Determinants and Survival of Reverse Mergers vs. IPOs,” Journal of Economics and Finance, 32, 176-194 (2008).

22 Kellogg, Charnes, supra, n.12.

24 Chordia, T, Huh, SW, Subrahmanyam, A, “Theory-Based Illiquidity and Asset Pricing," Review of Financial Studies, 22, 9, 3629-3668 (2009).

${ }^{25}$ Lesmond, D. A., J. P. Ogden, and C. A. Trzcinka, “A New Estimate of Transaction Costs,” Review of Financial Studies, 12, 5, 1113-1141 (1999).

26 For measuring liquidity in emerging markets, the Zeros measure has been used by: Bekaert, G, Harvey, CR, Lundblad, C, “Liquidity and Expected Returns: Lessons from Emerging Markets," Review of Financial Studies, 20, 1783-1831 (2007); Zhang, H, “Measuring Liquidity in Emerging Markets,” National University of Singapore Working Paper.

${ }^{27}$ Amihud, Y., "Illiquidity and Stock Returns: Cross-Section and Time Series Effects," Journal of Financial Markets, 5, 1, 31- 56 (2002).

${ }^{28}$ See Acharya, Viral and Lars H. Pedersen, “Asset Pricing with Liquidity Risk,” Journal of Financial Economics, 77, 2, 375- 410 (2005); Hasbrouck, Joel, “Trading Costs and Returns for U.S. Equities: Estimating Effective Costs from Daily Data,” 64, 3, 1445-1477 (2009); among others.

${ }^{29}$ Chordia, Huh, Subrahmanyam, supra, n.24.

30 Degeorge, F, Derrian, F, Womack, K, “Analyst Hype in IPOs: Explaining the Popularity of Bookbuilding,” Review of Financial Studies, 20, 4, 1021-1058 (2007). 